\title{
METAL CONCENTRATION STUDY IN A POPULATION LIVING IN THE VICINITY OF AN OIL REFINERY
}

\author{
ANTE CVITKOVIĆ ${ }^{1,2}$, KRUNOSLAV CAPAK ${ }^{3}$, JASNA JURASOVIĆ $^{4}$, ANDREJA BARIŠN $^{3}$, \\ IGOR IVIĆ-HOFMAN ${ }^{1}$, VEDRAN POLJAK ${ }^{3} \&$ MARIJANA VALJETIĆ ${ }^{1}$ \\ ${ }^{1}$ Institute of Public Health of Brod-Posavina County, Slavonski Brod, Croatia \\ ${ }^{2}$ Josip Juraj Strossmayer University of Osijek, Faculty of Medicine, Croatia \\ ${ }^{3}$ Croatian Institute of Public Health, Zagreb, Croatia \\ ${ }^{4}$ Institute of Medical Research and Occupational Health, Zagreb, Croatia
}

\begin{abstract}
The aim is to evaluate the exposure of Slavonski Brod citizens to metals from the environment: lead, cadmium, mercury, arsenic, nickel, manganese and thallium. Concentrations of $\mathrm{Pb}, \mathrm{Cd}, \mathrm{Hg}, \mathrm{As}, \mathrm{Ni}, \mathrm{Mn}$ and $\mathrm{Tl}$ were analyzed in the whole blood and/or serum, urine and hair of 40 examinees from Slavonski Brod. According to "wind rose" data and the vicinity of the oil refinery, examinees were divided in two groups: Group I with 20 examinees ( 17 females $/ 3$ males) and Group II with 20 examinees ( 13 females $/ 7$ males). Metals were analyzed using inductively coupled plasma mass spectrometry. Analysis accuracy was confirmed with reference samples. The difference between the groups was tested using the Mann-Whitney U test. Reference values were taken from German commission for biomonitoring, biomonitoring studies with Canadian examinees, Mayo Medical Laboratories reference values, USA and London Pathology, and Laboratory Medicine from Canada. There was no difference in age between the groups (Group I: $\mathrm{x}=48.2$; $\mathrm{SD} \pm 15.2$; Group II: $\mathrm{x}=50.7 ; \mathrm{SD} \pm 21.7 ; \mathrm{z}=-0.590 ; p=0.555$ ). Statistically significant differences were determined in As in blood (Group I: M = 2.10; Group II: $\mathrm{M}=3.20 ; \mathrm{z}=-3.414 ; p=0.0006$ ), in $\mathrm{Tl}$ in blood (Group I: $\mathrm{M}=0.012$; Group II: $\mathrm{M}=0.021$; $\mathrm{z}=-2.37 ; p=0.018$ ), in $\mathrm{Pb}$ in urine (Group I: $\mathrm{M}=0.71$; Group II: $\mathrm{M}=1.20 ; \mathrm{z}=-2.12 ; p=0.034$ ) and in $\mathrm{Mn}$ in urine (Group I: $\mathrm{M}=0.19$; Group II: $\mathrm{M}=0.11 ; \mathrm{z}=2.04 ; p=0.042$ ).

In Group I, one patient had elevated cadmium in hair $(0.227 \mu \mathrm{g} / \mathrm{g})$, the second had elevated arsenic in urine $(78.73 \mu \mathrm{g} / \mathrm{L})$, the third had elevated mercury in blood $(16.53 \mu \mathrm{g} / \mathrm{L})$ and hair $(2021 \mu \mathrm{g} / \mathrm{kg})$; in Group II, one had elevated lead in urine $(6.88 \mu \mathrm{g} / \mathrm{L})$ and hair $(8.39 \mu \mathrm{g} / \mathrm{g})$, the second had elevated cadmium in urine $(3.11 \mu \mathrm{g} / \mathrm{L})$, the third had elevated cadmium in blood $(2.98 \mu \mathrm{g} / \mathrm{L})$, the fourth had elevated lead in blood $(171.9 \mu \mathrm{g} / \mathrm{L})$ and urine $(20.1 \mu \mathrm{g} / \mathrm{L})$, and the fifth had elevated lead in urine $(10.01 \mu \mathrm{g} / \mathrm{L})$. The conclusion of this study is that the differences between the two groups are within referent values and this study should be expanded with more subjects and more parameters.
\end{abstract}

Keywords: metals, oil refinery.

\section{INTRODUCTION}

Health risks of air pollution in the EUROPE-HRAPIE project showed that relevant stakeholders and experts perceive six emission source categories (of a total of 16) identified by respondents pose an emerging health risk: road transport $(40.7 \%)$, space heating and air conditioning (15.0\%), shipping (8.8\%), energy production and distribution $(6.2 \%)$, industrial processes (metal industries) (6.2\%) and agriculture (5.3\%) [1]. When it comes to metals, except metals in general (1.0\%) several of them are particularly emphasized: arsenic $(1.1 \%)$, cadmium (1.3\%), mercury $(0.8 \%)$, lead $(1.7 \%)$, nickel $(2.3 \%)$, copper $(1.4 \%)$, zinc $(1.0 \%)$, manganese $(1.6 \%)$, iron $(2.0 \%)$, antimony $(1.1 \%)$, vanadium $(2.0 \%)$, aluminum $(0.1 \%)$ and transition metals in general $(0.3 \%)[1]$.

In 2008, in the city of Brod (Bosnia and Herzegovina) an oil refinery only a few hundred meters away from the city of Slavonski Brod (Croatia), started to operate. The impact of refineries on the environment is well known from different studies. High contents of nickel and vanadium were found in the vicinity of Rijeka, Zagreb and Sisak (Croatia) as a result of their emission from oil refinery, thermal power plant and industrial processes [2]. The results 
for groundwater samples exceeded European primary drinking water standards for $\mathrm{Fe}$ $(>200 \mu \mathrm{g} / \mathrm{l})$ and $\mathrm{Mn}(>50 \mu \mathrm{g} / \mathrm{l})$, while the levels of the trace metals are below the thresholds for drinking water quality were taken within the Pančevo Oil Refinery (Serbia) [3]. Concentrations of trace metals were found (mg/kg) to be for Mn: 656, Fe: 26734, Ni: 32.3, $\mathrm{Zn}: 72.8, \mathrm{~Pb}: 13.4$ and $\mathrm{Cu}: 27.0$. within an oil refinery Pančevo (Serbia) [4]. Results from Venezuela in the area of largest oil refinery complex indicated that levels of pollution of particular contaminants such as $\mathrm{Hg}, \mathrm{Pb}, \mathrm{Cd}$ and $\mathrm{TPH}$ in sites close to the oil refineries that have been operating in the area for decades are above local and international recommended standards [5]. The most relevant contaminants for all of the tested sites were $\mathrm{Cr}, \mathrm{Cu}, \mathrm{Ni}$, and $\mathrm{Zn}$ in a petrochemical area of Sardinia (Italy) [6]. Moreover, the accumulation of $\mathrm{Cr}$ and $\mathrm{Zn}$ in the refinery industrial areas was more than five times greater than that detected at the control site [7].

Inhalation of metal through air is the primary route of exposure for a large number of elements [8], [9]. For example, $\mathrm{Al}$ and $\mathrm{Fe}$ are basic component of aerosols resulting from the composition of the earth's crust, $\mathrm{As}, \mathrm{Cd}, \mathrm{Cr}, \mathrm{Co}, \mathrm{Cu}, \mathrm{Hg}, \mathrm{Mn}, \mathrm{Ni}, \mathrm{Pb}, \mathrm{V}$ and $\mathrm{Zn}$ occur as fossil fuels combustion products, $\mathrm{Cd}, \mathrm{Cu}$ and $\mathrm{Pb}$ are connected to electronic waste while workers in specific industrial plants, such as battery plants, foundries, refineries and metal industry continuously exposed through the respiratory system mostly $\mathrm{Fe}, \mathrm{Mn}, \mathrm{Mo}, \mathrm{Ni}$ and $\mathrm{Cr}$, as well as many other metals [8], [9]. The primary route of exposure to a large number of elements is by inhalation of metals through air. In that way, $\mathrm{Al}$ and $\mathrm{Fe}$ are components of aerosols resulted of the composition of earth's crust. As, $\mathrm{Cd}, \mathrm{Cr}, \mathrm{Co}, \mathrm{Cu}, \mathrm{Hg}, \mathrm{Mn}, \mathrm{Ni}, \mathrm{Pb}, \mathrm{V}$ and $\mathrm{Zn}$ are generated by burning fossil fuels, whereby $\mathrm{Cd}, \mathrm{Cu}$ and $\mathrm{Pb}$ are connected to electronic waste [8], [9]. Workers and specific industrial plants, such as the battery factory, foundry, refineries and the metal industry are continuously exposed through the respiratory system mostly Fe, Mn, Mo, Ni and Cr, as well as many other metals [8], [9].

The composition of the ambient air is constantly changing; therefore, the monitoring of ambient air quality to detect the changes caused by aerogenic pollutants makes the essential part of general environmental monitoring. To achieve more effective improvement of the ambient air quality, the Directive 2008/50/EC on 'Ambient Air Quality and Cleaner Air for Europe' was adopted by the European Parliament and the European Council countries [7].

The biomonitoring study clearly shows that adolescents living in the Milazzo-Valle del Mela area have increased urinary levels of cadmium which requires an action to reduce human exposure [10]. Besides, this study will serve as a basis for the health risk assessment and management process to favor the implementation of preventive measures to control emissions from the industrial plants of the area [10].

In a report of air pollution monitoring in the city of Slavonski Brod, contribution of possible sources (from biomass burning, traffic, industry and oil refinery) to levels of different inorganic and organic pollutants were studied [11]. It was shown that oil refinery in Brod, that predominantly contributed to sulfur compounds, contributed also to number of elements (Ni 84.9\%, Cr 73.9\%, Pb 2.7\%, Mn 8.5\%, V 57.6\%, La 81.5\%) [11].

\section{SUBJECTS AND METHODS}

\subsection{Subject selection}

Samples were collected in November 2016 in Slavonski Brod. Institute of Public Health of Brod-Posavina County conducted the selection of the subjects. Subjects were divided into two groups according to residence area: Group I with 20 subjects (17 females and 3 males), living in the northern part of the City of Slavonski Brod, and Group II with 20 subjects 
(13 females and 7 males) living in the city centre or in the southern part of the city. The division is made according to the "wind rose" data given by the Croatian Meteorological and Hydrological Service and the proximity of the Brod oil refinery, located in Bosnia and Herzegovina. The participants in Group I are at beeline of approx. $7.7 \mathrm{~km}$, and the participants of group 2 at the beeline of approximately $1-2.5 \mathrm{~km}$ of the Brod oil refinery. The entire survey originally included 630 subjects, citizens of Slavonski Brod (Croatia). Of these, 333 questionnaires were collected in Group II, and 297 in Group I. Of the total 630 contacted subjects, 497 underwent laboratory blood analysis, spirometry and ECG recordings. After applying the exclusionary criteria (anamnestic data on work in the metal industry, smoking and agreement to participate in the research), 40 subjects (20 in Group I and 20 in Group II) were selected for this research. In Group II one of the subjects was excluded after metal analyses were performed (due to outlier values for $\mathrm{Pb}$ ) and additional interview confirmed earlier professionally exposure to metals. All subjects gave written consent for voluntary and anonymous participation in the research. The General Hospital "Dr. Josip Benčević" Ethics Committee has given permission for the implementation of the study.

\subsection{Metal analysis}

The analyses of lead $(\mathrm{Pb})$, cadmium $(\mathrm{Cd})$, mercury $(\mathrm{Hg})$, arsenic (As), nickel (Ni), manganese $(\mathrm{Mn})$ and thallium (Tl) in whole blood was performed at the Institute for Medical Research and Occupational Health. Method of inductively coupled plasma mass spectrometry (ICP-MS) and instrument $7500 \mathrm{cx}$ Agilent (Agilent Technologies, Japan) was used. The accuracy of the analysis is confirmed by the analysis of the reference of blood samples (Seronorm Whole Blood Level I, II and III, Sero, Norway), serum (Seronorm Serum Level I and II, Sero, Norway), urine (Urine Seronorm Level I and II, Sero, Norway) and hair (NIES Human Hair 13). The concentration of creatinine in the urine, used for normalization of urinary metal concentrations, was determined by spectrophotometry (Cary 50, Varian, Australia), using the standard Jaffé method. The accuracy of the analysis is confirmed using Seronorm Urine (Nycomed, Norway) reference sample of urine with a certified concentration of creatinine.

\subsection{Statistical analysis}

Data were expressed as median (range) or means with standard deviations (SD). Differences between the groups were tested by Mann-Whitney U test due to the skewed distribution of the data in most of the variables. Spearman correlation was used to test univariate associations. The level of statistical significance was set at $5 \%(P<0.05)$. Statistical analysis was carried out using the STATISTICA version 13 (StatSoft, Inc., USA).

\section{RESULTS}

The mean age \pm standard deviation (SD) of the participants was $49.4 \pm 12.3$ years, and there was no statistically significant difference between the groups $(48.2 \pm 15.2$ in Group I and $50.7 \pm 21.7$ in Group II). However, it is important to note that age distribution was somewhat different: in Group I the youngest participant was 21 years old and only 1 participant was older than 70 years, while in Group II there were 3 participants younger than 18 years and 4 participants older than 70 .

Results of the analysis of the concentrations of $\mathrm{Pb}, \mathrm{Cd}, \mathrm{Hg}, \mathrm{As}, \mathrm{Ni}, \mathrm{Mn}$ and $\mathrm{Tl}$ in whole blood (Pb-B, Cd-B, Hg-B, As-B, Mn-B, Tl-B) or serum (Ni-S), urine (Pb-U, Cd-U, Hg-U, As-U, Ni-U, Mn-U, Tl-U) and hair (Pb-Hair, Cd-Hair, Hg-Hair, As-Hair, Ni-Hair, Mn-Hair, 
Tl-Hair) in participants living near (Group I) or at greater distance from oil refinery are shown in Table 1. The difference between groups was tested using the Mann-Whitney $U$ test and the results are shown in the same table.

Regarding results in particular subjects that were higher than reference values [12]-[16] in Group I one of the participants had elevated Cd-Hair $(0.227 \mu \mathrm{g} / \mathrm{g})$ and $\mathrm{Mn}$-Hair $(0.67 \mu \mathrm{g} / \mathrm{g})$, the second one As-U $(78.7 \mu \mathrm{g} / \mathrm{L})$, the third one $\mathrm{Hg}-\mathrm{B}(16.5 \mu \mathrm{g} / \mathrm{L})$ and $\mathrm{Hg}$-Hair $(2.02 \mu \mathrm{g} / \mathrm{g})$, and the forth one $\mathrm{Hg}-\mathrm{U}(3.6 \mu \mathrm{g} / \mathrm{g}$ creat.) while in Group II one of the participants had elevated $\mathrm{Pb}-\mathrm{B}(84.8 \mu \mathrm{g} / \mathrm{L}), \mathrm{Pb}-\mathrm{U}(6.9 \mu \mathrm{g} / \mathrm{L})$ and $\mathrm{Pb}-\mathrm{Hair}(8.4 \mu \mathrm{g} / \mathrm{g})$, the second one Cd-U $(3.1 \mu \mathrm{g} / \mathrm{L})$, the third one Cd-B $(3.8 \mu \mathrm{g} / \mathrm{L})$, the fourth one Pb-U $(10.0 \mu \mathrm{g} / \mathrm{L})$ and the fifth one Mn-Hair $(0.64 \mu \mathrm{g} / \mathrm{g})$.

Table 1: Median and range values of the analyzed parameters and statistically significant difference (Z, p, Mann Whitney U test) between groups in subjects living in two different area of the city Slavonski Brod, Croatia: Group I from northern part; Group II from center and south, in the vicinity of Brod oil refinery.

\begin{tabular}{|c|c|c|c|c|}
\hline & $\begin{array}{l}\text { Group I } \\
(N=\mathbf{2 0})\end{array}$ & $\begin{array}{l}\text { Group II } \\
(N=19)\end{array}$ & $\mathbf{Z}$ & $p$ \\
\hline $\mathrm{Pb}-\mathrm{B}(\mu \mathrm{g} / \mathrm{L})$ & $12.1(7.3-26.4)$ & $18.7(7.89-84.8)$ & -1.475 & 0.140 \\
\hline $\mathrm{Pb}-\mathrm{U}(\mu \mathrm{g} / \mathrm{L})$ & $0.71(0.35-1.68)$ & $1.20(0.11-10.0)$ & -2.121 & 0.034 \\
\hline $\mathrm{Pb}-\mathrm{U}$ ( $\mu \mathrm{g} / \mathrm{g}$ creat.) & $0.63(0.28-1.62)$ & $0.69(0.26-6.63)$ & -1.447 & 0.148 \\
\hline $\mathrm{Pb}$-Hair $(\mu \mathrm{g} / \mathrm{kg})$ & $307(105-3538)$ & $345(51.8-8390)$ & -0.660 & 0.509 \\
\hline $\mathrm{Cd}-\mathrm{B}(\mu \mathrm{g} / \mathrm{L})$ & $0.27(0.12-0.56)$ & $0.30(0.13-2.98)$ & -0.323 & 0.747 \\
\hline $\mathrm{Cd}-\mathrm{U}(\mu \mathrm{g} / \mathrm{L})$ & $0.24(0.08-0.79)$ & $0.27(0.02-3.11)$ & -0.548 & 0.584 \\
\hline Cd-U ( $\mu \mathrm{g} / \mathrm{g}$ creat.) & $0.24(0.09-1.05)$ & $0.23(0.05-2.00)$ & -0.211 & 0.833 \\
\hline Cd-Hair $(\mu \mathrm{g} / \mathrm{kg})$ & $3.41(1.61-227)$ & $6.63(1.54-18.5)$ & -0.941 & 0.347 \\
\hline $\mathrm{Hg}-\mathrm{B}(\mu \mathrm{g} / \mathrm{L})$ & $0.41(0.05-16.5)$ & $0.27(0.11-2.38)$ & 0.239 & 0.811 \\
\hline $\mathrm{Hg}-\mathrm{U}(\mu \mathrm{g} / \mathrm{L})$ & $0.19(0.02-3.63)$ & $0.16(0.01-1.75)$ & 0.492 & 0.623 \\
\hline Hg-U ( $\mu \mathrm{g} / \mathrm{g}$ creat.) & $0.17(0.05-3.76)$ & $0.11(0.02-0.89)$ & 0.997 & 0.319 \\
\hline Hg-Hair $(\mu \mathrm{g} / \mathrm{kg})$ & $104(20.7-2021)$ & $110(23.5-1595)$ & 0.098 & 0.922 \\
\hline As-B $(\mu \mathrm{g} / \mathrm{L})$ & $2.10(0.60-3.92)$ & $3.20(2.73-4.72)$ & -3.414 & 0.0006 \\
\hline As-U $(\mu \mathrm{g} / \mathrm{L})$ & $4.16(0.73-78.7)$ & $5.77(0.64-15.6)$ & -0.913 & 0.361 \\
\hline As-U ( $\mu \mathrm{g} / \mathrm{g}$ creat.) & $3.61(1.85-45.5)$ & $3.72(1.59-11.3)$ & 0.155 & 0.877 \\
\hline As-Hair ( $\mu \mathrm{g} / \mathrm{kg})$ & $8.05(3.57-47.0)$ & $11.2(2.91-33.2)$ & -1.026 & 0.305 \\
\hline $\mathrm{Ni}-\mathrm{S}(\mu \mathrm{g} / \mathrm{L})$ & $0.76(0.33-1.47)$ & $0.69(0.28-0.86)$ & 1.250 & 0.211 \\
\hline $\mathrm{Ni}-\mathrm{U}(\mu \mathrm{g} / \mathrm{L})$ & $2.48(0.92-3.97)$ & $2.62(0.25-3.82)$ & -0.098 & 0.922 \\
\hline $\mathrm{Ni}-\mathrm{U}$ ( $\mu \mathrm{g} / \mathrm{g}$ creat.) & $2.02(0.95-4.98)$ & $1.79(0.77-3.43)$ & 1.559 & 0.119 \\
\hline Ni-Hair $(\mu \mathrm{g} / \mathrm{kg})$ & $103(44.4-1104)$ & $82.7(46.9-165)$ & 1.250 & 0.211 \\
\hline $\mathrm{Mn}-\mathrm{B}(\mu \mathrm{g} / \mathrm{L})$ & $8.81(5.51-15.9)$ & $9.1(4.51-13.7)$ & 0.604 & 0.546 \\
\hline $\mathrm{Mn}-\mathrm{U}(\mu \mathrm{g} / \mathrm{L})$ & $0.23(0.06-0.51)$ & $0.15(0.01-0.41)$ & 1.784 & 0.074 \\
\hline Mn-U ( $\mu \mathrm{g} / \mathrm{g}$ creat.) & $0.19(0.04-0.87)$ & $0.11(0.04-0.77)$ & 2.037 & 0.042 \\
\hline Mn-Hair $(\mu \mathrm{g} / \mathrm{kg})$ & $143(55.6-2273)$ & $140(54.9-637)$ & 1.082 & 0.279 \\
\hline Tl-B $(\mu \mathrm{g} / \mathrm{L})$ & $0.012(0.002-0.053)$ & $0.021(0.003-0.045)$ & -2.374 & 0.018 \\
\hline $\mathrm{Tl}-\mathrm{U}(\mu \mathrm{g} / \mathrm{L})$ & $0.17(0.03-0.52)$ & $0.18(0.02-0.81)$ & -0.323 & 0.747 \\
\hline Tl-U ( $\mu \mathrm{g} / \mathrm{g}$ creat.) & $0.16(0.09-0.36)$ & $0.13(0.06-0.35)$ & 1.138 & 0.255 \\
\hline Tl-Hair $(\mu \mathrm{g} / \mathrm{kg})$ & $0.25(0.01-1.4)$ & $0.198(0.001-2.51)$ & 0.829 & 0.407 \\
\hline
\end{tabular}




\section{DISCUSSION}

The main objective of this pilot study was to examine levels of several metals in blood or serum, urine and hair in selected participants from the city of Slavonski Brod, Croatia and particularly, to investigate possible effect of oil refinery on the population living in its vicinity. To our knowledge, this is the first study of human biomonitoring of metals in the city area.

The concentration of $\mathrm{Pb}, \mathrm{Cd}, \mathrm{Hg}, \mathrm{As}, \mathrm{Ni}, \mathrm{Mn}$ and $\mathrm{Tl}$ were determined in biological samples of 39 subjects of both sexes ( 29 females and 10 males). Subjects were divided into two groups with regard to the residence area and its proximity to the Brod oil refinery. Median concentrations of the all measured metals in blood or serum, urine and hair were within reference values published for general population in different countries [12]-[16]. However, there were several participants with elevated levels of $\mathrm{Pb}, \mathrm{Cd}$ and $\mathrm{Hg}$ in blood, urine and hair, As in urine and $\mathrm{Mn}$ in hair. Elevated $\mathrm{Cd}, \mathrm{Hg}$, As and Mn levels in several participants can be attributed to specific nutritional or lifestyle habits. Namely, to explain increased Cd levels, more detailed information on smoking habit history or passive exposure to cigarette smoke as $\mathrm{Cd}$ is the most abundant metal detected in the tobacco plant, transferred and easily absorbed from the mainstream smoke. Fish and seafood products consumption are related to increase in organic $\mathrm{Hg}$ (blood and hair) and As (blood, urine and hair) concentrations, but the possible source of exposure to inorganic $\mathrm{Hg}$ in one participant with increased $\mathrm{Hg}$ urine concentration should be clarified [8]. Levels of Mn, an element that can be both essential and toxic to humans, can be elevated if dark hair coloring was used. However, elevated $\mathrm{Pb}$ levels in participants from Group II are probably due to environmental exposure source and that have to be further elucidated.

There was no significant difference between the groups in the concentrations of $\mathrm{Cd}, \mathrm{Hg}$ and $\mathrm{Ni}$ in the analyzed biological samples. There was significantly higher median $\mathrm{Pb}$ urine concentration (expressed in $\mu \mathrm{g} / \mathrm{L}$ ) in Group II in comparison to Group I. When urinary $\mathrm{Pb}$ concentrations are normalized against creatinine, the difference was not statistically significant. However, taking into account relatively small number of subjects in the study and clear trends of increased $\mathrm{Pb}$ blood, urine and hair levels in subjects living in the vicinity of oil refinery in comparison to subjects living further from refinery, noted difference in $\mathrm{Pb}$ either due to traffic, refinery or other source of exposure should be studied in more details, including higher number of participants. There was statistically significant difference between the groups in concentration of As and $\mathrm{Tl}$ in the blood and they were higher in the Group II. Concentration of $\mathrm{Mn}$ in the urine was higher in Group I. These differences, however, are toxicologically irrelevant, because they are within the reference values and ranges for the general population, and are determined in biological samples that are not considered as a reliable indicator of exposure to $\mathrm{As}, \mathrm{Tl}$ and $\mathrm{Mn}$.

This pilot study of human biomonitoring of metals in Slavonski Brod showed increased concentrations of at least of one analyzed metal in ca $25 \%$ of the subjects. Due to the small number of subjects and lack of the "real" control group (population living in the area further from oil refinery than Group I in this study) it was not possible to assess if living in the vicinity of oil refinery is associated with increased metal concentration.

\section{CONCLUSION}

This study is "pilot" study and it should certainly be expanded due to small number of subjects. In further studies, some other parameters like V and $\mathrm{Cr}$ should be included. The differences found between concentrations of metals in both groups are not toxicologically relevant because the concentrations of metals are within referent values. 


\section{ACKNOWLEDGEMENTS}

The authors express their gratitude to the colleagues Tatjana Orct, $\mathrm{PhD}$, Jelena Macan, $\mathrm{PhD}$, M.D. and Rajka Turk, MSc from the Institute for Medical Research and Occupational Health for their expert assistance in analyzing or interpreting data.

\section{REFERENCES}

[1] Henschel, S. \& Chan, G., Health risks of air pollution in Europe - HRAPIE project. New emerging risks to health from air pollution - results from the survey of experts. WHO Regional Office for Europe, World Health Organization, Copenhagen, 2013. www.euro.who.int/en/health-topics/environment-and-health/air-quality/ publications/2013/health-risks-of-air-pollution-in-europe-hrapie-project.-newemerging-risks-to-health-from-air-pollution-results-from-the-survey-of-experts. Accessed on: 27 Feb. 2017.

[2] Vučković, I., Špirić, Z., Stafilov, T., Kušan, V. \& Bačeva, K., The study on air pollution with nickel and vanadium in Croatia by using moss biomonitoring and ICPAES. Bull Environ Contam Toxicol, 91(4), pp. 481-487, 2013.

[3] Relić, D., Dorđević, D., Popović, A., Jadranin, M. \& Polić, P., Fractionation and potential mobility of trace metals in Danube alluvial aquifer within an industrialized zone. Environ Monit Assess, 171(1-4), pp. 229-248, 2010.

[4] Relić, D., Đorđević, D., Popović, A. \& Blagojević, T., Speciations of trace metals in the Danube alluvial sediments within an oil refinery. Environ Int, 31(5), pp. 661-669, 2005.

[5] Croquer, A., Bone, D., Bastidas, C., Ramos, R. \& García, E., Monitoring coastal pollution associated with the largest oil refinery complex of Venezuela. Peer $J$, 4(e2171), pp. 1-25, 2016.

[6] Cortis, P., Vannini, C., Cogoni, A., De Mattia, F., Bracale, M., Mezzasalma, V. \& Labra, M., Chemical, molecular, and proteomic analyses of moss bag biomonitoring in a petrochemical area of Sardinia (Italy). Environ Sci Pollut Res Int, 23(3), pp. 2288-2300, 2016.

[7] Baltrėnaitė, E., Baltrėnas, P., Lietuvninkas, A., Serevičienė, V. \& Zuokaite, E., Integrated evaluation of aerogenic pollution by air-transported heavy metals $(\mathrm{Pb}, \mathrm{Cd}$, $\mathrm{Ni}, \mathrm{Zn}, \mathrm{Mn}$ and $\mathrm{Cu}$ ) in the analysis of the main deposit media. Environ Sci Pollut Res Int, 21(1), pp. 299-313, 2014.

[8] Nordberg, G.F, Fowler, B.A., Nordberg, M. \& Friberg, L. (eds), Handbook on the Toxicology of Metals, 3rd ed., Academic Press Inc: Salt Lake City, 2007.

[9] Bogadi-Šare, A., Macan, J., Pleština, R., Turk, R. \& Zavalić, M., Kemijske štetnosti. Medicina rada i okoliša, eds M. Šarić \& E. Žuškin, Medicinska Naklada: Zagreb, pp. 129-275, 2002.

[10] Interdonato, M., et al., Levels of heavy metals in adolescents living in the industrialised area of Milazzo-Valle del Mela (northern Sicily). J Environ Public Health, 2014, pp. 1-9, 2014.

[11] Izvještaj o praćenju onečišćenja zraka na privremenoj postaji državne mreže za praćenje kvalitete zraka- Slavonski Brod (Za razdoblje 7. studenog 2013. - 8. kolovoza 2014.) (in Croatian), Institut za medicinska istraživanja i medicinu rada, Jedinica za higijenu okoline, Online. iszz.azo.hr/iskzl/datoteka?id=19830. Accessed on: 1 Feb. 2017.

[12] Goulle, J.-P., et al., Metal and metalloid multi-elementary ICP-MS validation in whole blood, plasma, urine and hair. Reference values. Forensic Sci Int, 153, pp. 39-44, 2005 . 
[13] Kommission "Human-Biomonitoring" des Umweltbundesamtes, Stoffmonographie Arsen - Referenzwert für Urin. Bundesgesundheitsbl - Gesundheitsforsch Gesundheitsschutz, 46, pp. 1098-1106, 2003.

[14] Kommission "Human-Biomonitoring" des Umweltbundesamtes, Aktualisierung der Referenzwerte für Blei, Cadmium und Quecksilber im Blut und Urin von Erwachsenen. Bundesgesundheitsbl - Gesundheitsforsch - Gesundheitsschutz, 46, pp. 1112-1113, 2003.

[15] Kommission "Human-Biomonitoring" des Umweltbundesamtes, Aktualisierung der Stoffmonographie Cadmium - Referenz- und Human Biomonitoring (HBM) -Werte. Bundesgesundheitsbl, 54, pp. 1098-1106, 2011.

[16] Mayo Clinic, Mayo Medical Laboratories, Interpretive Handbook, Online. http://www.mayomedicallaboratories.com/interpretive-guide/index.html. Accessed on: 27 Feb. 2017. 